FESIEE

Fundación Emilio Soldevilla de la Envestigación y Desarnosto

de la Economia de la Empresa

\section{Management Letters / Cuadernos de Gestión}

journal homepage: http://www.ehu.eus/cuadernosdegestion/revista/es/

ISSN: 1131-6837 / e-ISSN: 1988-2157

\title{
Explanatory and predictive drivers of entrepreneurial orientation and innovation capacity: Evidence from family enterprises
}

\section{Variables explicativas y predictivas de la capacidad de emprendimiento e innovación: evidencia en las empresas familiares}

\author{
Alfredo Martínez-Bobillo*, Juan Antonio Rodríguez-Sanz ${ }^{\mathrm{a}}$, Fernando Tejerina-Gaite ${ }^{\mathrm{b}}$ \\ a Catedrático de Economía Financiera. Universidad de Valladolid. Facultad de CC. Económicas y Empresariales. Avenida Valle de Esgueva. 6. 47011-Valladolid \\ (España)-juanantonio.rodriguez@uva.es - https://orcid.org/0000-0001-7228-4020 \\ ${ }^{b}$ Profesor Titular Universidad de Economía Financiera. Universidad de Valladolid. Escuela Ingeniería Informática. Campus Miguel Delibes. 47011-Valladolid \\ (España)-ftejerina@efc.uva.es - http://orcid.org/0000-0001-6301-0757
}

* Corresponding author: Catedrático de Economía Financiera. Universidad de Valladolid. Facultad de CC. Económicas y Empresariales. Campus Esgueva. 47011-Valladolid (España) -alfredo.martinez@uva.es - http://orcid.org/0000-0003-2488-8174

\section{A R T I C L E I N F O}

Received 29 June 2020

Accepted 12 December 2020

Available online 25 February 2021

DOI: 10.5295/cdg.201329am

JEL CODE: M10, M14

\begin{abstract}
A B S T R A C T
This paper aims to identify potential explanatory variables of the entrepreneurial orientation and innovation capacity (EO-IC) of family enterprises (FEs) through a comparative study of family businesses in Spain and Latin America. The innovation literature reports a paradigm shift whereby the dynamic boost provided by corporate governance and productivity is playing an increasing role as a driver of EO-IC and sustainable competitive advantage. This issue acquires particular relevance in the case of family firms, where entrepreneurial and innovation capacities are characteristically hampered by socio-emotional and risk-aversion factors. We construct a panel of data on 182 large family enterprises (1,820 observations) domiciled in Argentina, Brazil, Chile, Colombia, Mexico, Peru, Uruguay and Spain, drawing on the Thomson Onebanker and ORBIS databases for the period 2008-2018. The results reveal the emergence of new explanatory variables for the structure of the family-firm EO-IC framework, some related to productivity; others more basically to corporate governance. They also show that, in Latin America, the use of business efficiency (productivity) factors in the planning and potentiation of EO-IC by family firms is hampered by the institutional (legal, regulatory, labour and educational) environment, where traditional factors such as firm size and ownership concentration are more relevant. In the Spanish case, however, the evidence points to a transition from traditional inputs towards business efficiency and productivity-related factors.
\end{abstract}

Keywords: family firm, entrepreneurial orientation, innovation capacity, corporate governance, productivity, Latin America vs. Spain.

\section{R E S U M E N}

El presente trabajo pretende analizar las variables explicativas de la orientación emprendedora y la capacidad de innovación de la empresa familiar (EO-IC) en un estudio comparativo de las empresas familiares españolas y latinoamericanas. A este respecto, se constata un cambio de paradigma en la literatura sobre innovación en el que las capacidades dinámicas derivadas del gobierno corporativo y de la productividad han ido cobrando progresiva importancia en la conformación de la (EO-IC) y en la consecución de una ventaja competitiva sostenible. Esta problemática cobra especial interés en el caso de la empresa familiar, donde las implicaciones socioemocionales y la aversión al riesgo, características de este tipo de empresa, ponen habitualmente en tela de juicio su capacidad para innovar y emprender. Construimos un panel con 182 grandes empresas familiares (1.820 observaciones) pertenecientes a Argentina, Brasil, Chile, Colombia, México, Perú, Uruguay y España, utilizando las bases de datos Thomson Onebanker y ORBIS para el período 2008-2018. Los resultados obtenidos evidencian la aparición de nuevas variables explicativas en la configuración de la (EO-IC) de la empresa familiar, basadas en la productividad y fundamentalmente en el gobierno corporativo. De la misma manera, en la empresa familiar latinoamericana, se constata cómo el entorno institucional (legal, regulatorio, laboral y educativo) frena la utilización de variables de eficiencia (productividad), en favor de otras variables más tradicionales como tamaño y concentración de la propiedad en el diseño y fortalecimiento de la OE CI. En el caso español, sin embargo, se evidencia la transición de variables tradicionales hacia factores relacionados con la eficiencia y productividad empresarial.

Palabras clave: empresa familiar, capacidad emprendedora, capacidad de innovación, gobierno corporativo, productividad, Latinoamérica vs. España. 


\section{INTRODUCTION}

The globalization of the economy carries both risks and opportunities for today's society. Within this context, the transformation of its component units, such as businesses, faces the global market with the challenge of constant adaptation (Craft 2000). Automation, standardization and distribution formed the bulwark of firm modernization in the last century, whereas the identity of the twenty-first century is based on the use of information technologies (ICTs) grounded in the automation and digitalization of the economy (Pavitt 2005). These dynamics are driving the transformation towards higher industrial specialization, featuring small businesses equipped with the latest-generation technology. Thus, in an environment as volatile, uncertain, complex and ambiguous as the current one, the key to firm survival and sustainable competitive advantage across all sectors will be to invest in innovation.

Against this background, analysis of the possible repercussions of entrepreneurial orientation and innovation capacity (EO-IC) in all firms, particularly family enterprises (FEs), gains special relevance. Given an endowment of resources and specific capabilities that could either stimulate or hinder EO-IC activities, FEs provide an exceptional context for a case-study of EO-IC development (Habbershon et al. 2003; Nordqvist et al. 2008; Zellweger et al. 2010). The close ownership-management relationship characteristic of the FE could have a decisive influence on the various dimensions of EO-IC (innovation, risk, pro-activeness, aggressive competitiveness and autonomy) (Zahra 2005; Casillas et al. 2011; Hernández-Linares and López-Fernández 2018).

In light of the above, any growth and profitability differences among FEs could be due to variations in resource endowments, especially with respect to intangible resources, where acquisition, replication, accumulation and imitation by rival firms are more difficult (Barney 1991). Among the various intangible resources, R\&D investment, human capital training and corporate reputation are worth exploring as the three basic strategic inputs for building firms' competitiveness (Huselid 1995; Roberts and Dowling 2002; Cho and Pucik 2005). The Resource-Based View (RBV) theory therefore serves as a potentially useful tool for explaining EO-IC in the EF in terms of intangible asset investment ( $R \& D$, human capital training, reputation). Various studies supporting this idea, point towards a shift from the use of tangible to intangible resources as leverage for more efficient exploitation of assets and the achievement of competitive advantage over rivals (Orlitzky et al. 2003; Rua 2018; Khan et al. 2019). However, the process through which these resources drive competitive advantage is unclear, having even been dubbed by the strategic management literature as "the missing link" (Chatzoglou. et al. 2018). Recent research suggests that firms use these resources to strengthen their dynamic skills and capabilities and thus gain an edge over their rivals (Teece 2007; Wu 2010).

Some of the variables cited in the literature as innovation and entrepreneurship conditioners are country-level factors. Duran et al. (2016) mention minor shareholder protection or the skills level of the country's labour force as paradigmatic examples of institutional drivers. Our study attempts to contribute to the search for the explanatory variables of EO-IC in the FE in two contrasting institutional environments (Latin America and Spain) where the internal and external barriers to entrepreneurship and innovation are potentially so diverse. Some issues worth highlighting related to the labour market (skills development problems and labour contracts), internal organizational factors (lack of funds and readiness for change in management and the workforce), and the institutional environment (the fiscal treatment of R\&D investment; minor shareholder protection; development of the financial system; scientific and technical knowledge; governance regulations). This study calls for investigation into the main contributing factors and indicators of the capacity for sustainable competitive advantage driven by growth and profitability and based on EO-IC in FEs; that is, corporate governance, corporate strategy and performance or value creation (Gómez-Mejía et al. 2014).

The research on corporate governance and its relationship with EO-IC considers variables such as the family's involvement in management (Arzubiaga et al. 2018; Calabrò et al. 2020); CEO generation (Durán et al. 2016); family ownership concentration (Gómez-Mejía et al. 2014; Decker and Günther 2017; Arzubiaga et al. 2018); or the volume of external resources (Nieto et al. 2015).

With respect to corporate strategy variables, the research focuses on the relationship between EO-IC and the productivity of labour and capital, particularly in the FE. Thus, Block (2010) claims that sole ownership by the founder has a positive impact on EO-IC and also on intangible asset productivity. In a similar vein, Classen et al. (2014) in a comparative analysis of innovation activity in FEs and non-FEs find higher levels of tangible asset productivity and lower innovation costs in FEs, albeit with a lower level of labour productivity relative to non-FEs. However, Morck and Yeung (2003) highlight that an aversion to investment in tangible assets hampers the productivity of innovation investment in FEs. Finally, Zellweger (2007) claims that, due to their focus on long-term objectives, FEs are more likely to rely on tangible investment to strengthen their EO-IC.

Finally, in several studies value-added or resource-creation variables are found to explain innovation in the FE. Internal and family resources play an essential role; firstly, because access to external funding is limited by small firm size or guarantee shortage and, secondly, because conflict can arise between external investors focused on short-term profits and the family who have a long-term commitment to socio-emotional wealth preservation (Cruz et al. 2012).

Our research objective, therefore, is to compare the behaviour of these variables in Latin American and Spanish FEs and check for variation attributable to differences in the legal-institutional framework, financial system or cultural environment. This study contributes to the literature on FEs and the tendency to innovate in several ways. One is to provide a fuller understanding of the process through which intangible assets can lead to a competitive advantage for FEs, the distinctive characteristics of which provide a novel context for exploring the underlying factors of EO-IC or any of its dimensions (innovation, pro-activeness, and risk assumption). Another is to probe deeper into the impact of the new variables (relating to corporate governance, corporate strategy and performance) on EO-IC. In this way, we aim to validate the reported effects of the paradigm shift on entrepreneurship in general and the FE in particular. Finally, our study will analyse the gap in terms of family firm EO-IC between two institutional environments as diverse as Latin America and Spain, thereby admitting the possible influence of institutional factors which could help to explain the relationship that concerns us. 
Our study continues as follows. Section 2 comments on the main theories on EO-IC developed in the business management literature, taking into consideration the analysis of the component dimensions of corporate governance, corporate strategy and value added. Section 3 describes the specification of the empirical model for testing our hypotheses using data on 182 large family firms (1,820 observations for the period 2008-2018) domiciled in Argentina, Brazil, Chile, Colombia, Mexico, Peru, Uruguay and Spain. Section 4 gives the interpretation of the results, and the paper concludes in Section 5 with a general discussion and summary of the findings.

\section{THEORY AND HYPOTHESES}

\subsection{Corporate governance mechanisms, business strategy, internal funding and EO-IC in the family enterprise}

As stated in the introduction, entrepreneurial activity promotes creativity and innovation and is a transcendental means to long-term survival for FEs (Arzubiaga 2019). The characteristics of these firms in terms of ownership and governance structure, corporate strategy and emphasis on internal funding provide an ideal case study for the analysis of innovation and entrepreneurship issues (Steier 2003; Lumpkin et al. 2005).

A joint socio-emotional wealth (SEW) and resource-based (RBV) approach is a useful choice for the study of non-complex, intangible-intensive organizations, such as FEs (Habbershon and Williams 1999; Gómez-Mejía et al. 2011). Our first area of analysis concerns the family ownership level and percentage of family board members and the implications of these for the FE corporate governance structure and its relationship with EO-IC.

In this respect, higher ownership concentration and a lower degree of board autonomy from family control lead to heavier investment in human and financial capital and higher profitability gains (Andres 2008; Munari et al. 2010). This lack of autonomy increases the emotional burden on family members and their commitment to the business. Thus, the greater the involvement of family owners in EO-IC decisions, the stronger their tendency to prioritize family concerns over business interests (Le Breton-Miller et al. 2011). The current owners will want to do everything in their power to hand down the family business and wealth to future generations, and will therefore take a cautious and discouraging attitude with respect to EO-IC (Gómez-Mejía et al. 2010). Thus, a large family ownership could have a negative effect on its EO-IC performance (Chrisman and Patel 2012). This leads us to propose our first hypothesis:

H1: High family ownership concentration or board dependence on the family will have a negative impact on EO-IC in the FE.

Borrowing is another FE corporate governance practice which is closely related to family control and managerial discretion through two mechanisms: the use of free cash flow and the ambidextrous nature ${ }^{1}$ of innovation investment.

Ambidextrous in the sense of simultaneous innovation exploration and exploitation.
With respect to managerial discretion in free cash flow usage, it is worth noting that tight control by a majority of family ownership could dissuade non-family managers from the discretionary use of free cash flow, especially in large firms. However, the responsibility for strategic EO-IC decisions lies with top management team (TMT), in line, specifically, with long-term survival objectives, which could be hampered by excessive family control over the use of free cash flow (Talke et al. 2010).

Meanwhile, a preference for autonomy and family control clearly impacts on owners' financing decisions (Dreux 1990). Thus, some authors describe entrepreneurs prioritizing autonomy and using their own resources or retained profits to finance innovation (Shrivastiva and Grant 1985; Hutchison 1995), while Stoney and Winstanley (2001) report that family firms' aversion to shared ownership drives them to use credit for that purpose. Meanwhile, Van der Wijst (1989) claims that new generation CEOs show less resistance to borrowing and a greater willingness to embrace non-family investment. Various studies find an association between a control-oriented family business plan and a higher propensity to borrow.

Furthermore, the low-risk investment decisions typical of FEs bring the interests of majority family shareholders closer into line with those of creditors than those of minority shareholders, thereby easing access to credit from financial markets (Croci et al. 2011).

The above reasoning motivates the following hypothesis:

H2: The use of debt financing in FEs, associated with family control and constraints on managerial discretion, will have a positive impact on the financing of EO-IC activities.

Another variable with potentially significant implications for EO-IC development is the proportion of family managers and degree of generational diversity on the board of directors (Murphy and Lambrechts 2015; Querbach et al. 2020). Family involvement in the management team fosters a propensity towards EO-IC activities through family members' strong commitment to firm survival (Casillas et al. 2011). Meanwhile, younger generations, being less risk averse, more highly trained, and more diverse than their predecessors, are able to contribute tacit knowledge of business processes and information passed down by previous generations (Kellermanns 2008). This leads us to formulate the following hypothesis:

H3: A higher proportion of family board members and greater generational board diversity have a positive impact on EO-IC in FEs.

The distinctive management and succession patterns of family firms enable the identification of certain traits of corporate strategy (basically, the productivity of capital and labour) relating to their levels of innovation, risk taking and pro-activeness in EO-IC (Habbershon and Pistrui 2002; Lumpkin et al. 2005). The resource-based theory claims that a company's profits are due in large part to the stock of tangible and intangible resources (Barney 1991; Aiello et al. 2020) which it uses to build EO-IC capacity as a means to gain a competitive advantage and thereby promote long-term survival. Thus, a firm's critical assets in terms of knowledge, entrepreneurial capacity and innovation ultimately reside in its human and tangible capital. Calabrò et al. (2020) show precisely how the presence of family board members contributes to the accumulation and efficient use of intangible assets $(R \& D$, tacit knowledge) and thereby improves EO-IC in the family firm. 
Based on these assumptions we posit the following hypothesis: H4: Tangible/intangible and labour productivity are positively related to EO-IC in the EF.

One of the main potential obstacles to EO-IC is access to internal or external financial resources. According to the behavioural agency theory and the socio-emotional wealth perspective (Kotlar et al. 2018), external funding through new equity issues can lead to conflict between the long term goals of the current generation of family owners and the short-term goals usually adopted by external investors. The EO-IC process, therefore, works better if the external investors are specialized in some area and able to provide value-added services as well as financial resources (Cirillo et al. 2019). According to Benfratello et al. (2008), the main form of R\&D investment in the private sector is through internal financing. Muñoz-Bullón and Sánchez-Bueno (2011) note that FEs have less opportunity for R\&D investment because of an internal resource deficit, which in many cases forces them to seek credit or other forms of external funding. In short, the desire to perpetuate the family dynasty and maintain control over assets makes the owners of family businesses more inclined to use internal than external funding to finance R\&D investments (Bacci et al. 2018; Kupp et al. 2019).

Therefore we propose the following hypothesis:

H5: There is a positive link between internal resource generation and EO-IC in the FE.

\subsection{Institutional environment and EO-IC in the FE: Latin America vs. Spain}

A comparative analysis of entrepreneurial capacity and innovation in the $\mathrm{FE}$ in institutional contexts as disparate as those of Latin America and Spain will help us to determine whether the explanatory power for the process underlying EO$\mathrm{CI}$ resides in institutional or country-level factors. From precisely this institutional perspective, Duran et al. (2016) reach the conclusion that the impact of family-firm characteristics on innovation performance varies between environments with different levels of minority shareholder protection or workforce education.

Family firms still make a decisive contribution to national economies in areas such as tangible and labour competitiveness, export volume or job creation. In developing countries, family firms form the nucleus of new business creation and wealth transfer (Carney 2007). Similarly, the prevalence of FEs in a given geographical area stimulates cooperation and thereby the creation and ongoing development of innovations (Block and Spiegel 2013). As a consequence, Latin America is a geographical area of rapid growth and international influence. With a population of around 600 million, it is a major supplier of raw materials for manufacturing markets where it has partnerships with leading companies worldwide (Nicholson 2011). Family firms form the majority in this area of the world (Pérez and Lluch 2016) and thus provide a context of unsurpassable research relevance. The contrasting cultural, legal and financial contexts of Spain and Latin America will determine the potential influence of corporate governance, corporate strategy and value creation variables on EO-IC in their respective FEs.
Three institutional factors that could impact differently on Latin American and Spanish FEs are the economic and financial environment, the political and social context and the legal framework. Speaking from the financial and economic angle, we could say that Latin America has switched from a policy of regional protectionism in the 1960s (Lansberg and Perrow 1991) to one of destabilizing and deeply challenging trade openness. This switch was instigated by the leading countries of Latin America (Argentina, Brazil, Mexico, Colombia, etc.) in a process beginning with state intervention and gradually evolving towards the privatization of businesses (Gras and Mendoza-Abarca 2014).

Latin American countries are characterized by the shallowness of their banking systems (credit/GDP ratio below 50\%), which raises the cost of banking services. Another characteristic feature is small bank size, which prevents economies of scale and the adoption of new technologies that would boost competitiveness and enable a more fluid and efficient relationship with the business sector. Many Latin American economies are highly dollarized, a fact which leaves their financial systems more vulnerable to solvency and liquidity risks while conditioning their lending policy towards businesses.

Spain's geopolitical environment, on the other hand, which features a deregulated financial system with a low degree of government intervention, a high level of protection for minority investors and a recent history of multiple bank mergers, has acted as a lever for improving corporate productivity and efficiency. Another important factor which should not be overlooked is that the European Union has a single currency and a market with 400 million potential consumers. Four decades of financial stability within the context of the European single market, therefore, have boosted the competitiveness, funding potential and growth capacity of Spain's family businesses. At the political and social level, meanwhile, three key contrasting factors between Latin American and Spanish firms have their origin in the constant economic changes in Latin American economies which have created an environment of social conflict that has triggered a migratory flow to the cities, which accommodate $80 \%$ of the population (UNEP 2010). The results of these population shifts are higher unemployment, structural deficits, and education systems with insufficient capacity to train a skilled workforce (Poza 1995; Nordqvist et al. 2011). These social issues are also reflected in business organizations, which have been forced into a process of constant evolution and adaptation to government norms and policies (Lansberg and Perrow 1991).

The second notable factor is the strong political involvement of some family managers of FEs. In countries where political instability is the norm, dual commitment to family and business interests on the one hand and government policies on the other can create potential conflicts of interest within the family and even among board members. A third and last peculiarity of the Latin American family enterprise is its youthfulness in comparison with those of Europe or North America. This, together with a high concentration of family ownership, forms a so-called group-structured business with a single and clear objective, which is none other than to pave the way for new family generations. This results in multigenerational involvement and 
sufficient decision-making autonomy to enable the promotion of EO-IC within the firm. In Spain, on the other hand, only exceptionally does one find either politically involved board members or corporate diversification in family firms.

With respect to legal frameworks, Cabrera-Suárez and Santana-Martín (2004) note that FE corporate governance practices are inevitably affected by the legal framework within which they operate. Both Latin America and Spain have civil law systems, traditionally associated with low-level protection for minority shareholders and high corporate ownership concentration ( $\mathrm{La}$ Porta et al. 1999; Faccio and Lang 2002). In Spain, however, EU regulations (Directive 2017/828), developed by the Central European Bank and incorporated into Spanish stock market rules, promote market transparency and prevent the diversion of profits by large shareholders. This is far from the case in Latin America, where the weakness of the legal system can lead to the replacement of state functions by FEs. Thus, we can observe how micro-enterprises emerge in so-called subsistence entrepreneurship (Beckert and Dewey 2017), small and medium-sized family businesses grabbing economic opportunities as they arise (Basco and Calabrò 2016), or large family conglomerates using a search strategy and exploiting any available profit-making opportunity (Morck and Yeung 2003; Robles et al. 2016). In short, we can say that the EU geopolitical environment has enabled Spain to achieve generally higher business competitiveness levels in all firms, FEs included.

Given the above, the climate of greater uncertainty surrounding Latin American FEs necessitates a high level of flexibility and adaptability in their EO-IC management, a fact which differentiates them from their Spanish counterparts in terms of corporate governance structure (Monteferrante and Piñango 2011).

These characteristic differences between the Latin American and Spanish business contexts suggest the following hypotheses:

H6: Corporate governance variables have more impact on EOIC in Latin American FEs than in Spanish ones.

H7: Labour and capital productivity variables have less impact on EO-IC in Latin American FEs than in Spanish ones.

H8: Firm size and hi tech sector affiliation have a stronger positive impact on EO-IC in Latin American FEs than in Spanish ones.

\section{DATA AND METHODOLOGY}

\subsection{Data}

The sample for this study is formed from individualized family-firm cross-industry data drawn from the Orbis (Bureau van Dyjk) database for Spain and Latin America (Argentina, Brazil, Chile, Colombia, Costa Rica, Mexico and Peru) and for a period running from 2008 to 2018. The corporate governance data were taken from a report on Europe, the USA and Latin America published by Heidrick \& Struggles Consultors for the same period of analysis. Executive compensation elasticities were calculated from Boardex and ExecuComp. Data firm distributions by country and sector affiliation are shown in Tables 1 and 2, where it can be seen that the initial sample comprised 180 firms $(1,800$ observations) with full data-availability for each of the study pe- riods, thus constituting a balanced panel. To achieve the research objective of comparing innovation policies in two distinct contexts, $44 \%$ of the sample refers to Spanish FEs ( 80 firms), and the remaining 56\% to Latin American FEs (100 firms).

Table 1

Sample distribution by countries (2008-2018)

\begin{tabular}{lcccc}
\hline \multicolumn{1}{c}{ Country } & N. firms & \multicolumn{1}{c}{$\%$} & N. observations & \% \\
\hline Argentina & 17 & $9.44 \%$ & 170 & $9.44 \%$ \\
Brazil & 17 & $9.44 \%$ & 170 & $9.44 \%$ \\
Chile & 18 & $10,00 \%$ & 180 & $10,00 \%$ \\
Colombia & 18 & $10,00 \%$ & 180 & $10,00 \%$ \\
Spain & 80 & $44.44 \%$ & 800 & $44.44 \%$ \\
Mexico & 18 & $10,00 \%$ & 180 & $10,00 \%$ \\
Perú & 12 & $6.67 \%$ & 120 & $6.67 \%$ \\
\hline Total & 180 & $100 \%$ & 1800 & $100 \%$ \\
\hline
\end{tabular}

Source: Own elaboration

Table 2 shows the distribution of firms and observations by industries, all of which are adequately represented, with Manufacturing (29\%) and Trade (23\%) forming the majority.

Table 2

Number of firms per sector

\begin{tabular}{|c|c|c|c|c|}
\hline SECTOR & $\begin{array}{l}\mathrm{N} . \\
\text { firms }\end{array}$ & $\%$ & $\begin{array}{c}\text { N. } \\
\text { observ. }\end{array}$ & $\%$ \\
\hline 1. Mining and Construction & 20 & $11.11 \%$ & 200 & $11.11 \%$ \\
\hline $\begin{array}{l}\text { 2. Food. Beverages. Tobacco. } \\
\text { Wood. Cork and Paper. }\end{array}$ & 53 & $29.44 \%$ & 530 & $29.44 \%$ \\
\hline $\begin{array}{l}\text { 3. Metals and metal products. } \\
\text { Machinery. Equipment. } \\
\text { Furniture and Recycling }\end{array}$ & 22 & $12.22 \%$ & 220 & $12.22 \%$ \\
\hline $\begin{array}{l}\text { 4. Transport and } \\
\text { Communications. Gas. } \\
\text { Electricity and Water }\end{array}$ & 15 & $8.33 \%$ & 150 & $8.33 \%$ \\
\hline 5. Wholesale and Retail & 42 & $23.33 \%$ & 420 & $23.33 \%$ \\
\hline $\begin{array}{l}\text { 6. Banks and other Financial } \\
\text { Services }\end{array}$ & 11 & $6.11 \%$ & 110 & $6.11 \%$ \\
\hline $\begin{array}{l}\text { 7. Services: Hotels and } \\
\text { Restaurants. Automobile } \\
\text { Repairs }\end{array}$ & 8 & $4.44 \%$ & 80 & $4.44 \%$ \\
\hline $\begin{array}{l}\text { 8. Other Services: Health. } \\
\text { Education. Social. Museums } \\
\text { and Consulting }\end{array}$ & 9 & $4.94 \%$ & 90 & $4.94 \%$ \\
\hline Total & 180 & $100.0 \%$ & 1800 & $100.0 \%$ \\
\hline
\end{tabular}

Source: Own elaboration

\subsection{Variables}

The empirical estimation uses the regression model described more fully in the next section and the variables described below (further details in Table 3 ). 
Table 3

List of variables

\begin{tabular}{|c|c|c|c|}
\hline Dependent Variable & & & References \\
\hline $\begin{array}{l}\text { Entrepreneurship and } \\
\text { innovation capacity }\end{array}$ & $E O-I C_{i . t}=\frac{I A_{i . t}-I A_{i . t-1}}{\text { Sales }_{i . t}-\text { Sales }_{i . t-1}}$ & $\begin{array}{l}\text { Investment in intangibles (R\&D } \\
\text { expenditure, human capital } \\
\text { formation, and goodwill) over } \\
\text { sales variation from } \mathrm{t} \text { to } \mathrm{t}-1\end{array}$ & $\begin{array}{l}\text { Miller et al. (2015) } \\
\text { Surroca et al. (2010) } \\
\text { Heirman and Clarysse (2007) }\end{array}$ \\
\hline \multicolumn{4}{|l|}{ Independent Variables: } \\
\hline \multicolumn{4}{|l|}{ A) Corporate governance } \\
\hline Ownership Concentration & $\mathrm{C}_{i . t}$ & $\begin{array}{l}\text { Percentage ownership held by } \\
\text { top } 5 \text { shareholders. }\end{array}$ & $\begin{array}{l}\text { Andres (2008) } \\
\text { Munari et al. (2010) } \\
\text { Brunninge and Nordqvist (2004) }\end{array}$ \\
\hline $\begin{array}{l}\text { Leverage: Degree of family } \\
\text { control and managerial } \\
\text { discretion }\end{array}$ & $L E V_{i . t}=\frac{\operatorname{Debt}_{i, t}}{\text { Assets }_{i . t}}$ & Total debt over total assets & $\begin{array}{l}\text { Stoney and Winstanley (2001) } \\
\text { Van der Wijst (1989) } \\
\text { Croci et al. (2011) }\end{array}$ \\
\hline Ownership status & IND & $\begin{array}{l}\text { Bureau van Dijk (Orbis) } \\
\text { Ownership independence } \\
\text { index which ranges from } 1 \text { to } 4\end{array}$ & $\begin{array}{l}\text { Aparicio et al. (2019) } \\
\text { Arzubiaga et al. (2018) }\end{array}$ \\
\hline $\begin{array}{l}\text { Presence of family } \\
\text { members and generational } \\
\text { diversity on the Board of } \\
\text { Directors }\end{array}$ & FAMILY & $\begin{array}{l}\text { Index constructed from Orbis } \\
\text { ownership data and equal } \\
\text { to the percentage of board } \\
\text { members with ties to the } \\
\text { controlling family }\end{array}$ & $\begin{array}{l}\text { Lee and Chu (2017) } \\
\text { Casillas and Moreno (2010) } \\
\text { Casillas et al. (2011) } \\
\text { Arzubiaga et al. (2018) } \\
\text { Murphy and Lambrechts (2015) }\end{array}$ \\
\hline \multicolumn{4}{|l|}{ B) Corporate strategy } \\
\hline $\begin{array}{l}\text { Intangible Capital } \\
\text { Productivity }\end{array}$ & $I P_{i . t}=\frac{\text { Intangibles }_{i, t}}{\text { Assets }_{i . t}}$ & Intangibles over total assets & $\begin{array}{l}\text { Habbershon and Pistrui (2002) } \\
\text { Lumpkin et al. (2005) } \\
\text { Calabrò et al. (2020) }\end{array}$ \\
\hline $\begin{array}{l}\text { Tangible Capital } \\
\text { Productivity }\end{array}$ & $\operatorname{TCP}_{i . t}=\frac{\text { Tangibles }_{i, t}}{\text { Assets }_{i . t}}$ & Tangibles over total assets & $\begin{array}{l}\text { Habbershon and Pistrui (2002) } \\
\text { Lumpkin et al. (2005) } \\
\text { Calabrò et al. (2020) }\end{array}$ \\
\hline Labour productivity & $L P_{i . t}=\frac{\text { Operating revenue }_{i, t}}{\text { N.Employees }}$ & $\begin{array}{l}\text { Operating revenue over } \\
\text { number of employees }\end{array}$ & $\begin{array}{l}\text { Habbershon and Pistrui (2002) } \\
\text { Lumpkin et al. (2005) } \\
\text { Calabrò et al. (2020) }\end{array}$ \\
\hline \multicolumn{4}{|c|}{ C) Performance measured as effective and efficient utilization of resources to generate sales } \\
\hline Added value & $A V_{i . t}=\frac{\text { Sales }_{i . t}-\text { Sales costs }_{i . t}}{\text { N.Employees }}$ & $\begin{array}{l}\text { Value added over number of } \\
\text { employees }\end{array}$ & $\begin{array}{l}\text { Benfratello et al. (2008) } \\
\text { Cirillo et al. (2019) } \\
\text { Bacci et al. (2018) }\end{array}$ \\
\hline \multicolumn{4}{|l|}{ D) Control Variables } \\
\hline $\begin{array}{l}\text { Free Cash } \\
\text { Flow }\end{array}$ & FCF / Sales i.t $_{\text {. }}=\frac{F C F_{i . t}}{\text { Sales }_{i . t}}$ & Free Cash Flow over total sales & $\begin{array}{l}\text { Michiels and Molly (2017) } \\
\text { Pindado et al. (2011) }\end{array}$ \\
\hline Firm age & LnAge & $\begin{array}{l}\text { Natural log of years since firm } \\
\text { foundation }\end{array}$ & $\begin{array}{l}\text { Huergo and Jaumandreu (2004) } \\
\text { Bianchi et al. (2015) }\end{array}$ \\
\hline Size & LnAssets & Natural $\log$ of total assets & $\begin{array}{l}\text { Chrisman et al. (2015) } \\
\text { Duran et al. (2016) }\end{array}$ \\
\hline Tech level & TECHCODE & $\begin{array}{l}\text { Index based on sector and } \\
\text { OECD data. Ranges from } 1 \text { to } 3\end{array}$ & $\begin{array}{l}\text { Kammerlander and Ganter (2015) } \\
\text { Garcés-Galdeano et al. (2016) }\end{array}$ \\
\hline
\end{tabular}

Source: Own elaboration based on theoretical literature review 
The dependent variable to be estimated is firms' entrepreneurship orientation and innovation capacity (EO-IC), taking entrepreneurship and innovation as R\&D and other intangible investment inputs (Anderson et al. 2012) proxied by the following variable:

$$
E O-I C_{i . t}=\frac{I A_{i . t}-I A_{i . t-1}}{\text { Sales }_{i . t}-\text { Sales }_{i . t-1}}
$$

where $I A_{\text {i.t. }}$ is the stock of intangible assets for firm $i$ for period $t$ and Sales is its total turnover for the same period. The same notation applies for period $t-1$.

The explanatory or independent variables included in the equations to be estimated are as follows.

The first set relates to Corporate Governance factors: (1) the percentage of capital held by the five main shareholders; (2) corporate debt measured as total debt over total assets; (3) ownership status and (4) the ratio of family and non-family board members.

Second, a group of firm productivity performance indicators; namely, the productivity of intangible (tangible) assets measured as intangible (tangible) investments over total assets; labour productivity, is calculated as operating revenue over the number of employees; and added value per employee measured as the sales/ cost ratio over the number of employees. ${ }^{2}$

A third set of variables captures other factors potentially contributing to entrepreneurship orientation and innovation capacity. The first is free cash flow (FCF), which is designed to capture discretionary use of financial slack and its potentially weakening impact on entrepreneurship and innovation capacity. Others are firm age, expressed as the natural $\log$ function of the number of years since inception; firm size, expressed as the natural log of total assets (a classic among the variables that might affect FE innovation capacity); and, finally, industry technological intensity, which is one of the potentially most transcendental variables for firm innovation capacity. For classification purposes, we use the sectoral classification guidelines of the OECD Directorate for Science, Technology and Innovation and Structural Analysis Statistics Division (OECD, 2011).

\subsection{Methodology}

Using the variables described in the previous section, we test the proposed hypotheses with two forms of data analysis. We begin with a descriptive analysis of the dependent variable and the three sets of explanatory variables proposed earlier, and then proceed to the explanatory stage by estimating the model for each set of determining factors of intangible investment intensity.

Using the proxy for corporate innovation capacity and the proposed explanatory variables, the equation to be estimated takes the following form.

$$
E O-I C_{i . t}=\alpha+\sum_{j=1}^{4} \beta^{j} C G_{i . t}^{j}+\sum_{k=1}^{4} \gamma^{k} P V_{i . t}^{k}+\sum_{l=1}^{4} \delta^{l} T V_{i . t}^{l}+\eta_{i}+\varepsilon_{i . t}
$$

2 Data on numbers of employees were obtained from the ORBIS database, web pages or via e-mail in the case of some Latin American firms.
In equation (1) the subscripts $i$ and $t$ refer to firm and time, respectively. The term $\boldsymbol{\beta}^{\mathbf{j}}$ is subdivided into four coefficients; one for each of the four governance variables under consideration: ownership concentration, debt, board autonomy and the percentage of family board members. The term $\gamma^{k}$ represents the 4 coefficients of the productivity variables: intangible assets, tangible assets, labour and value added. Finally, $\delta^{l}$ denotes the four traditional control variables included in the model: free cash flow, firm age, firm size, and industry technological intensity. Random noise is divided into two components: one denoted by $\varepsilon_{\mathrm{it}}$, which captures all the factors with a degree of impact on firm's innovation capacity and corresponds to the residual standard error. However, the so-called firm-fixed effects $\left(\eta_{i}\right)$ are usually included in the aforementioned noise term, which is potentially correlated with the explanatory variables and may lead to serious biases in the estimation. This "constant unobservable heterogeneity", which may go unnoticed, can be removed by means of first difference estimation. Moreover, the two-step estimator, which includes the first-stage residuals matrix, yields estimates robust to autocorrelation and heteroscedasticity (White 1980).

Nevertheless, since the endogeneity of the independent variables may pose a significant model estimation problem, we first tested for endogeneity in our model using the version proposed by Davidson and MacKinnon (1993) for fixed effects estimation using panel data, the results of which enable us to reject the null hypothesis of exogeneity for tangible and intangible productivity, labour productivity and debt. Ultimately, the most appropriate estimation technique is the Generalized Method of Moments (GMM) estimator proposed by Arellano and Bond (1991) and widely used in the empirical literature, which not only adjusts for simultaneity bias, but also enables us to handle a residual pattern robust to autocorrelation and heteroskedasticity.

The two-stage GMM estimator simultaneously estimates equations in first differences and in levels, thereby overcoming the weak instrument problem which is characteristic of GMM estimation. For the equations in differences, we use a single lag of the level variable, while for the equations in levels we use all the available lags of the first-differenced variables (Blundell and Bond 1998). The GMM system estimator controls for possible model misspecification and instrument validity is assessed by testing overidentifying restrictions, correlation between the instruments and random noise with Hansen's J. Non-rejection of the null hypothesis validates the instruments by ruling out their correlation with the error term (Pindado and Requejo 2014). Since we are using the first-difference GMM estimator, the transformed model should test for potential second-order correlation using the $\mathrm{m}_{2}$ statistic to avoid serial correlation problems. Finally, Wald's test is used to test the joint significance of the model coefficients.

\section{EMPIRICAL APPLICATION}

Stage one consisted of an initial descriptive analysis of the selected sample. Thus, Table 4 shows the means, standard deviations, and the minimum, maximum and median values 
of the study variable (entrepreneurship orientation and innovation capacity (EO-IC), and the main explanatory variables proposed in the theory and methodology section grouped into three sets: corporate governance variables (CG), productivity variables (PV) and traditional or control variables (TV).

Table 4

Descriptives for total sample

\begin{tabular}{|c|c|c|c|c|c|c|}
\hline Variables & \# Obs & mean & S.D. & $\min$ & $\max$ & median \\
\hline EO-IC & 1,255 & 0.0800 & 0.3192 & -0.5277 & 0.9987 & 0.0079 \\
\hline C5 & 1,820 & 0.6913 & 0.3768 & 0.00 & 100 & 0.89585 \\
\hline LEV & 1,388 & 0.5865 & 0.2038 & 0.2273 & 0.9077 & 0.6033 \\
\hline IND & 1,820 & 2.0247 & 1.0811 & 1 & 4 & 2 \\
\hline FAMILY & 1,820 & 0.5237 & 0.3202 & 0.05 & 1 & 0.5 \\
\hline ICP & 1,372 & 0.0576 & 0.0795 & 0 & 0.2822 & 0.0205 \\
\hline TCP & 1,372 & 0.3072 & 0.1911 & 0.0152 & 0.6872 & 0.2810 \\
\hline LP & 1,381 & 216.52 & 222.99 & 35.82 & 928.62 & 140.55 \\
\hline AV & 1,369 & 0.2747 & 0.1584 & 0.0649 & 0.6741 & 0.2379 \\
\hline FCFSALES & 1,099 & 0.0830 & 0.0732 & -0.0106 & 0.2696 & 0.0604 \\
\hline AGE & 1,820 & 52.850 & 36.17 & 6 & 110 & 41 \\
\hline ASSETS & 1,388 & 3.498 .728 & 5.644 .363 & 15.684 .14 & $1.94 \mathrm{E}+07$ & 752.506 \\
\hline EMPLOYEES & 1,388 & 29.824 & 62.220 & 2 & 516.421 & 3.537 \\
\hline TECHCODE & 1,810 & 1.5690 & 0.5777 & 1 & 3 & 2 \\
\hline
\end{tabular}

Source: Own elaboration.

Some values worth mentioning relate to the form of governance in the sample firms. The first notable feature is the high level of ownership concentration (69.13\%), a general characteristic of Spanish and Latin American firms alike and particularly pronounced in FEs. Another is high dependency on external resources as reflected in a mean leverage value of $58.65 \%$ with a median of $60.33 \%$. The ownership status indicators, taken directly from Bureau van Dijk's database, where values range from 1 (less autonomy) to 4 (more autonomy), show a mean value of 2.02. Finally, the percentage of family board members, unsurprisingly, reaches $52.37 \%$ on average.

The productivity values are hard to compare with no frame of reference, although they are considerably higher for tangible than for intangible assets. Table 4 also shows an average firm age of 52.85 years (with a median of 41 ), a high free cash flow margin ratio $(8.30 \%)$ and some bias towards low-tech sectors, as reflected in the mean value of the Tech Level variable, 1.56, which has a possible range of 1 to 3 .

The estimates of equation (1) for the total sample, shown in Table 5, reveal that the explanatory power for EO-IC in FEs lies in productivity factors, governance and the traditional control variables. Thus, tangible and intangible productivity and labour productivity (H4) and generated added value (H5) have a positive influence on innovation capacity, in complete con- trast to that of tangible investment; and widely disparate results emerge for the corporate governance factors. Both financial leverage (H2) and the percentage of family members on the board (H3) have a positive impact on EO-IC, while the impact of family ownership percentage (H1) and ownership status is negative. Finally, the results for the traditional variables reveal a positive impact on innovation from firm size and hi-tech industry affiliation, in line with expectations. Free cash flow and firm age, on the other hand, have a braking effect on R\&D investment. The AR2 statistic shows no second-order autocorrelation, while Hansen's J (see Section 3.3.) prevents rejection of the null hypothesis of no correlation between the instruments and the residuals of the GMM estimation, thereby validating the choice of instruments.

The analysis of joint significance ${ }^{3}$ by groups of variables given at the foot of Table 5 shows how the variables for corporate governance (family-specific assets), corporate strategy (capital and labour productivity) and internal resource creation (level of financial autonomy) reveal themselves as drivers of EO-IC in the family firm.

3 The joint significance results presented are for the productivity and corporate governance sets, given that value creation is composed of a single variable (VAP) and individual significance suffices. 
Table 5

Equation 1: Firm innovation capacity. GMM estimation

\begin{tabular}{|c|c|}
\hline \multicolumn{2}{|c|}{$\begin{array}{c}\text { Dependent variable } \\
\text { (EO-IC)-Entrepreneurship and innovation capacity }\end{array}$} \\
\hline \multicolumn{2}{|c|}{ Independent variables } \\
\hline ICP & $55.5831^{\star * *}$ \\
\hline & $(0.0000)$ \\
\hline \multirow[t]{2}{*}{ LP } & $0.0059^{* * *}$ \\
\hline & $(0.0000)$ \\
\hline \multirow[t]{2}{*}{ LNASSETS } & $4.8747^{\star * *}$ \\
\hline & $(0.0000)$ \\
\hline \multirow[t]{2}{*}{ TCP } & $-33.7116^{\star * *}$ \\
\hline & $(0.0000)$ \\
\hline \multirow[t]{2}{*}{ AV } & $6.8699^{* * *}$ \\
\hline & $(0.0000)$ \\
\hline \multirow[t]{2}{*}{ FCFSALES } & $-10.0217^{\star * *}$ \\
\hline & $(0.0000)$ \\
\hline \multirow[t]{2}{*}{ LNAGE } & $-0.8974^{\star *}$ \\
\hline & $(0.0153)$ \\
\hline \multirow[t]{2}{*}{ TECHCODE } & $4.7303^{\star * *}$ \\
\hline & $(0.0000)$ \\
\hline \multirow[t]{2}{*}{ C5 } & $-0.1486^{\star * *}$ \\
\hline & $(0.0000)$ \\
\hline \multirow[t]{2}{*}{ LEV } & $0.8936^{\star *}$ \\
\hline & $(0.0290)$ \\
\hline \multirow[t]{2}{*}{ IND } & $-2.4566^{* * *}$ \\
\hline & $(0.0002)$ \\
\hline \multirow[t]{2}{*}{ FAMILY } & $20.2103^{\star * *}$ \\
\hline & $(0.0000)$ \\
\hline Observations & 931 \\
\hline N. of firms & 142 \\
\hline \multirow[t]{2}{*}{ Chi-2 } & $4.550 \mathrm{e}+07$ \\
\hline & 0.000 \\
\hline \multirow[t]{2}{*}{ AR1 } & -1.522 \\
\hline & 0.128 \\
\hline \multirow[t]{2}{*}{ AR2 } & -0.980 \\
\hline & 0.327 \\
\hline \multirow[t]{2}{*}{ HANSEN TEST } & 123.7 \\
\hline & 0.876 \\
\hline Productivity & $21.87^{\star * *}$ \\
\hline (TCP, ICP, LP) & $(0.000)$ \\
\hline Corporate governance & $18.49^{* * *}$ \\
\hline (C5, LEV, IND, FAMILY) & $(0.000)$ \\
\hline
\end{tabular}

Source: Own elaboration. Coefficient estimates and $\mathrm{P}>|\mathrm{z}|$ (in parentheses). Hansen test distributed as follows: $\div 2$ with degrees of freedom equal to the number of estimated coefficients. ${ }^{* *},{ }^{* *},{ }^{*}$ : significant at the $1 \%, 5 \%$ and $10 \%$ levels respectively.
Table 6

Equation 1: Firm innovation capacity. GMM Estimation (Spain vs. Latin America)

Dependent variable

(EO-IC): Firm entrepreneurship orientation and innovation capacity

\begin{tabular}{lcc}
\hline \multicolumn{1}{c}{ Independent variables } & (1) FE-SPAIN & $\begin{array}{c}\text { (2) FE-LATIN } \\
\text { AMERICA }\end{array}$ \\
\hline ICP & $76.0370^{* * *}$ & $-21.0820^{* * *}$ \\
& $(0.0000)$ & $(0.0000)$ \\
LP & $0.0057^{* * *}$ & $0.0022^{\star}$ \\
& $(0.0003)$ & $(0.0574)$ \\
LNASSETS & $1.7660^{* * *}$ & $0.6149^{*}$ \\
& $(0.0000)$ & $(0.0640)$
\end{tabular}

TCP

$-19.1537^{\star * *} \quad-11.9655^{\star * *}$

(0.0000) (0.0002)

$-1.2777-4.2392^{* *}$

(0.3609) (0.0101)

FCFSALES $\quad-9.1167^{* * *} \quad 0.8235$

$(0.0000) \quad(0.3345)$

$\begin{array}{lll}\text { LNAGE } & 1.1777^{* *} & 0.8201\end{array}$

$18.6312^{* * *} \quad 3.0623^{* *}$

$(0.0000) \quad(0.0167)$

$-0.1410^{\star * *} \quad 0.0803^{\star * *}$

$(0.0000) \quad(0.0022)$

$15.3172^{\star * *} \quad 7.1954^{\star * *}$

$(0.0000) \quad(0.0064)$

$3.0280^{* * *} \quad 0.2627$

$(0.0017) \quad(0.7105)$

FAMILY

$32.4739^{* * *}$

$6.6575^{\star * *}$

$(0.0000) \quad(0.0049)$

Observations $\quad 556 \quad 375$

N. of firms $\quad 76 \quad 66$

$\begin{array}{lll}\text { Chi-2 } & 2.105 \mathrm{e}+06 & 2470\end{array}$

$0.000 \quad 0.000$

$-1.157 \quad-1.433$

$0.247 \quad 0.984$

$-1.006 \quad-0.962$

$0.314 \quad 0.336$

$59.60 \quad 23.21$

$0.871 \quad 0.152$

$56.88^{* * *} \quad-33.04^{* * *}$

Productivity

(ICP, TCP, LP)

$(0.0000)$

$(0.000)$

Corporate governance $\quad 50.67^{* * *} \quad 14.19^{* * *}$

(C5, LEV, IND, FAMILY) (0.000) (0.000)

Source: Own elaboration. Coefficient estimates and $\mathrm{P}>|\mathrm{z}|$ (in parentheses). Hansen test distributed as follows: $\div 2$ with degrees of freedom equal to the number of estimated coefficients. ${ }_{* * *}^{* *},{ }^{*}$ : significant at the $1 \%, 5 \%$ and $10 \%$ levels, respectively. 
Table 6 highlights the main differences in EO-IC explanatory factors found in the comparison of FEs based on geographical origin, with Spanish FE data reported in column 1 and Latin American FE data in column 2. The most striking difference lies with intangible productivity, which is positive in the case of Spanish FEs and negative in that of Latin American ones. Ownership structure, on the other hand, has a much greater influence in Latin American FEs, where high ownership concentration usually means a higher level of EO-IC; an effect that is not observed in Spanish FEs. Finally, one of the traditional variables, firm age, strikes another discordant note, by emerging as a valuable asset in Spanish FEs, while appearing irrelevant in those of Latin America. In summary, the analysis of joint significance reported in the bottom rows of Table 6, illustrates how the strongest EO-IC drivers for Spanish FEs (corporate strategy factors and internal resource creation) actually constitute barriers to the innovation process in Latin American FEs, where they have a strongly significant negative impact.

\section{DISCUSSION AND CONCLUSIONS}

Globalization and technological change have disrupted many aspects of society, particularly the business environment. Changes in social dynamics, together with the looming threat of artificial intelligence, have led to a new paradigm based on entrepreneurship orientation and innovation capacity (EO-IC). With respect to the business sector, this new paradigm plays a key role in market economies, where state-regulated free enterprise is the main driver of economic growth and development. Against this background, the family enterprise offers an exceptional research context which has already attracted the attention of the innovation and entrepreneurship literature. Despite the undeniable benefits of innovation, family firms have certain characteristics which prevent their wholehearted commitment towards it. Thus, the related literature echoes the point that FE traits such as family control, a simultaneous focus on financial and non-financial goals, or the need to conserve socio-emotional wealth make the FE a particularly worthwhile setting in which to explore the underlying factors of EO or any of its dimensions, including innovation, pro-activeness or risk assumption (Hernández-Perlines and Ibarra 2017; Arzubiaga et al. 2018; Hernández-Linares and López-Fernández 2018).

In order to analyse the key moderating factors in FE entrepreneurship behaviour, this study focuses on the three main sources of heterogeneity proposed by Gómez-Mejía et al. (2014): corporate governance, corporate strategy and performance, some of which have already been addressed individually by other authors (Arzubiaga et al. 2018). The results obtained show how the traditional variables of firm size and age, liquidity and industry affiliation have lost some of their explanatory power for EO-IC design and structure dynamics.

Nevertheless, these traditional control variables continue to feature in studies such as Hernández-Perlines and Ibarra (2017) and Arzubiaga et al. (2018). Indeed, Gómez-Mejía et al. (2014) highlight the role of the hi-tech sector, which they claim can alter the mixed gamble or trade-off between finan- cial and non-financial goals in the FE by incentivizing R\&D investment; a claim which is corroborated by our own study. In the mean time, however, other weightier indicators of entrepreneurship capacity and business innovation have been emerging. Corporate strategy variables, for example, should show a positive impact on EO-IC, as suggested by Gómez-Mejía et al. (2014) and as upheld by the results reported in this study for all the proposed productivity measures (tangible and intangible assets, added value and labour) except capital investment. The set of corporate governance variables emerge among the most influential, and authors such as Duran et al. (2016) emphasize the role played by corporate governance in innovation, heavily underlining the influence of factors relating to family control and ownership concentration. Our results hint at a reduction in risk aversion to the use of debt to stimulate FE growth and development. The presence of family board members, moreover, far from discouraging EO-IC, is seen as a driver, especially if the CEO belongs to a younger generation of the family dynasty. The concurrence of various generations on the board likewise has beneficial effects on EO-IC, by facilitating the discovery of new opportunities and novel entrepreneurial and innovation initiatives. In a study about board of directors in family firms, Arzubiaga et al. (2018) observe its negative repercussions on the transformation of entrepreneurship into innovation. However, the same authors obtain evidence showing the benefits from the involvement of the FE board of directors in designing service and control tasks or providing specialised knowledge and skills. Meanwhile, Gómez-Mejía et al. (2014) find that EO-IC in the FE improves with the participation of institutional investors. An analysis of the effect of family ownership concentration by Arzubiaga et al. (2018) proves inconclusive. According to our results, however, EO-IC in FEs suffers both from excessive family ownership and from too much ownership independence, which can lead to tensions between family and non-family board members.

Our proposal echoes the institutional theory, whereby innovation performance is largely determined by country-level factors (Duran et al. 2016). Thus, we analyse whether EO-IC in Latin American vs. Spanish FEs is influenced by the prevailing institutional (legal, economic and cultural) environment. Our results evidence the notable role of productivity variables in the EO-IC of Spanish FEs. The explanation for this could lie in the degree of autonomy in business decision making they are allowed by the Spanish legal and regulatory framework, as a consequence of which the Spanish FE tends to imitate the behaviour of private enterprise in general by exploiting the potential synergies to be gained from placing family members on the board of directors in order to control agency costs.

The influence of the institutional framework in the Latin American FE is rather different, however. Interaction between a weak legal and regulatory environment, labour market inefficiencies and a less developed education system enables an oligarchy formed by a few clans to influence State initiatives through the EO-IC. Under these conditions, and in the presence of weak internal and external governance mechanisms, the results show that the dominant role among the basic EO-IC parameters in the Latin American FE is played by variables relating to family ownership concentration, the presence of family members on 
the board of directors and a reliance on debt driven by an underdeveloped financial system.

This study presents a series of implications for professionals. Given the role of family firms as a pillar of economic and social development in both Spain and Latin America, their directors need to understand the enabling power of innovation and entrepreneurship, which can propel them to achieve sustainable competitive advantage. This paper identifies business strategy and ownership and governance factors as the main drivers in this respect, although their role varies considerably with the prevailing legal and institutional environment, such that the traditional variables and ownership factors play the leading role in the case of Latin America, while productivity and governance factors are the most influential in that of Spain.

Finally, while deepening understanding of innovation and entrepreneurship in the family enterprise, this study spotlights the need for further research. For instance, the reported findings are based on a set of eight Latin American countries grouped into a single sample, and could therefore lead to unjustified generalizations. The use of a sample of countries with a specific institutional profile or the inclusion of accurate indicators of institutional strength, minority shareholder protection, etc., will no doubt help to elucidate the influence of this key factor. Furthermore, while this study uses intangible investment as a proxy for entrepreneurship and innovation, the incorporation of more selective variables, such as R\&D expenditure, would no doubt help to corroborate or fine-tune the findings (Surroca et al. 2006; Gómez-Mejía et al. 2014; Duran et al. 2016). Finally, although our study considers some measurable features of the family business profile, such as the family's share of ownership and family involvement in the board of directors, the family business is a multidimensional concept and it would therefore be appropriate to analyse the influence of other dimensions, such as the generational stage of the business or the involvement of the family in its management (Casillas and Moreno 2011).

Summing up in relation to the issues raised in the introduction, the results obtained help to build understanding of the process whereby intangible assets lead to a competitive advantage for the FE. They therefore justify the inclusion of new explanatory variables in FE EO-IC patterns, based on productivity and corporate governance (family ownership, family CEO, multigenerational board composition and the presence of non-family board members). Furthermore, Latin American institutional (legal, regulatory, employment and education) frameworks are identified as the explanation for the insignificance of efficiency and productivity variables as compared with more traditional ones such as firm size and ownership concentration with respect to the design and development of EO-IC in the FEs of that part of the world.

\section{ACKNOWLEDGEMENTS}

The authors are grateful to Editor and two anonymous referees for suggestions and comments on previous version of the paper. This work was supported by the Spanish Ministry of Economy and Competitiveness [grant number ECO201784864-P].

\section{BIBLIOGRAPHY}

Aiello, F., Mannarino, L. and Pupo, V., 2020. Innovation and productivity in family firms: evidence from a sample of European firms. Economics of Innovation and New Technology, 29(4), 394-416.

Anderson, R.C., Duru, A. and Reeb, D.M., 2012. Investment policy in family controlled firms. Journal of Banking and Financing 36(6), 1744-1758.

Andres, C., 2008. Large shareholders and firm performance-An empirical examination of founding-family ownership. Journal of Corporate Finance, 14(4), 431-445.

Aparicio, G., Iturralde, T. and Sánchez-Famoso, V., 2019. Innovation in family firms: a holistic bibliometric overview of the research field. European Journal of Family Business, 9(2), 71-84.

Arellano, M., and Bond, S., 1991. Some tests of specification for panel data: Monte Carlo evidence and an application to employment equations. Review of Economic Studies, 58, 277-297.

Arzubiaga, U., 2019. Gobernanza corporativa y orientación emprendedora de las pymes familiares: un análisis de la influencia de la implicación familiar a distintos niveles. Cuadernos de Gestión, 19(1), 119-146.

Arzubiaga, U., Kotlar, J., De Massis, A., Maseda, A. and Iturralde, T., 2018. Entrepreneurial orientation and innovation in family SMEs: Unveiling the (actual) impact of the Board of Directors. Journal of Business Venturing, 33(4), 455-469.

Bacci, S., Cirillo, A., Mussolino, D. and Terzani, S., 2018. The influence of family ownership dispersion on debt level in privately held firms. Small Business Economics, 51(3), 557-576.

Barney, J., 1991. Firm resources and sustained competitive advantage. Journal of Management 17(1), 99-120.

Basco, R., 2015. Family business and regional development: A theoretical model of regional familiness. Journal of Family Business Strategy, 6, 259-271.

Basco, R., and Calabrò, A., 2016. Open innovation search strategies in family and non-family SMEs. Academia Revista Latinoamericana de Administración, 29(3), 279-302.

Battilana, J., Leca, B. and Boxenbaum, E., 2009. How actors change institutions: Towards a theory of institutional entrepreneurship. Academy of Management Annals, 3, 65-107.

Beckert, J. and Dewey, M., 2017. The architecture of illegal markets: Towards an economic sociology of illegality in the economy. Oxford University Press.

Beinhocker, E., Davis, I. and Mendonca, L., 2009. The 10 trends you have to watch. Harvard Business Review, 87, 55-60.

Benfratello, L., Schiantarelli, F. and Sembenelli, A., 2008. Banks and innovation: Microeconometric evidence on Italian firms. Journal of Financial Economics, 90(2), 197-217.

Bianchini, S., Krafft, J., Quatraro, F. y Ravix, J., 2015. Corporate governance, innovation and firm age: insights and new evidence. GREDEG Working Papers Series, 68(275).

Block, J., 2010. Family management, family ownership, and downsizing: Evidence from S\&P 500 firms. Family Business Review, 23(2), 109-130.

Block, J.H. y Spiegel, F., 2013. Family firm density and regional innovation output: An exploratory analysis. Journal of Family Business Strategy, 4(4), 270-280.

Blundell, R. y Bond, S., 1998. Initial conditions and moment restrictions in dynamic panel data models. Journal of Econometrics, 87(1), 115143.

Brunninge, O. y Nordqvist, M., 2004. Ownership structure, board composition and entrepreneurship. International Journal of Entrepreneurial Behavior \& Research, 10(1-2), 85-105.

Cabrera-Suárez, K.C., y Santana-Martín, D.J., 2004. Governance in Spanish family business. International Journal of Entrepreneurial Behavior \& Research, 10(1-2), 141-163. 
Calabrò, A., Torchia, M., Jimenez, D.G. and Kraus, S., 2020. The role of human capital on family firm innovativeness: the strategic leadership role of family board members. International Entrepreneurship and Management Journal, 1-27. Retrieved from: https://link.springer.com/article/10.1007/s11365-020-00657-y\#article-info. [Access: $13^{\text {th }}$ December 2020]

Carney, M., 2007. Minority family business in emerging markets: Organization forms and competitive advantage. Family Business Review, 20(4), 289-300.

Casillas, J.C. and Moreno, A.M., 2010. The relationship between entrepreneurial orientation and growth: The moderating role of family involvement. Entrepreneurship \& regional development, 22(3-4), 265-291.

Casillas, J.C., Moreno, A.M. and Barbero, J.L., 2011. Entrepreneurial orientation of family firms: Family and environmental dimensions. Journal of Family Business Strategy, 2(2), 90-100.

Cirillo, A., Pennacchio, L., Carillo, M.R. and Romano, M., 2019. The antecedents of entrepreneurial risk-taking in private family firms: CEO seasons and contingency factors. Small Business Economics, 1-20. Retrieved from: https://link.springer.com/article/10.1007\%2Fs11187-019-00279-x. [Access: $13^{\text {th }}$ December 2020].

Chatzoglou, P. and Chatzoudes. D., 2018. The role of innovation in building competitive advantages: an empirical investigation. European Journal of Innovation Management, 41, 46-73.

Cho, H.-J. and Pucik, V., 2005. Relationship between innovativeness, quality, growth, profitability, and market value. Strategic Management Journal, 26 (6), 555-575.

Chrisman, J.J., Chua, J.H. and Sharma, P., 2005. Trends and directions in the development of a strategic management theory of the family firm. Entrepreneurship Theory and Practice, 29(5), 555-575.

Chrisman, J. J. and Patel, P.J., 2012. Variations in R\&D investments of family and non-family firms: Behavioral agency and myopic loss aversion perspectives. Academy of Management Journal, 55(4), 976-997.

Chrisman, J.J., Chua, J.H., De Massis, A., Frattini, F. and Wright, M., 2015. The ability and willingness paradox in family firm innovation. Journal of Product Innovation Management, 32(3), 310-318.

Chua, J.H., Chrisman, J.J., Steier, L.P. and Rau, S.B., 2012. Sources of heterogeneity in family firms: An introduction. Entrepreneurship Theory and Practice, 36(6), 1103-1113.

Classen, N., Carree, M., Van Gils, A., and Peters, B., 2014. Innovation in family and non-family SMEs: an exploratory analysis. Small Business Economics, 42(3), 595-609.

Crafts, N.F.R., 2000. Globalization and Growth in the Twentieth Century. No. 00/44. International Monetary Fund.

Croci, E., Doukas, J.A. and Gonenc, H., 2011. Family control and financing decisions. European Financial Management, 17(5), 860-897.

Cruz, C., Justo, R., and De Castro, J.O., 2012. Does family employment enhance MSEs performance?: Integrating socioemotional wealth and family embeddedness perspectives. Journal of business venturing, 27(1), 62-76.

Davidson, R. and MacKinnon, J.G., 1993. Estimation and Inference in Econometrics. Oxford University Press, New York.

De Massis, A., Di Minin, A. and Frattini, F., 2015. Family-Driven Innovation. California Management Review, 58(1), 5-19.

Decker, C., and Günther, C., 2017. The impact of family ownership on innovation: evidence from the German machine tool industry. Small Business Economics, 48(1) 199-212.

Deming, D., 2017. The growing importance of social skills in the labour market. NBER Working Paper, $\mathrm{n}^{\circ} 2147$.

Dreux, D.R., 1990. Financing family business: Alternatives to selling out or going public. Family Business Review, 3, 225-243.

Dunn, B., 1996. Family enterprises in the UK: A special sector? Family Business Review, 9(2), 139-155.
Duran, P., Kammerlander, N., Van Essen, M. and Zellweger, T., 2016. Doing more with less: Innovation input and output in family firms. Academy of Management Journal, 59(4), 1224-1264.

Dyer, W.G., 2003. The family: The missing variable in organizational research. Entrepreneurship Theory and Practice, 27(4), 401-416.

Eddleston, K.A., Kellermanns, F.W. and Sarathy, R., 2008. Resource configuration in family firms: Linking resources, strategic planning and technological opportunities to performance. Journal of Management Studies, 45(1), 26-50.

Faccio, M. and Lang, L.H., 2002. The ultimate ownership of Western European corporations. Journal of Financial Economics, 65(3), 365-395.

Garcés-Galdeano, L., Larraza-Kintana, M., García-Olaverri, C. and Makri, M., 2016. Entrepreneurial orientation in family firms: the moderating role of technological intensity and performance. International Entrepreneurship and Management Journal, 12(1), 27-45.

Gómez-Mejía, L.R., Makri, M., and Kintana, M.L., 2010. Diversification decisions in family-controlled firms. Journal of Management Studies, 47(2), 223-252.

Gómez-Mejía, L.R., Cruz, C., Berrone, P. and De Castro, J., 2011. The bind that ties: Socioemotional wealth preservation in family firms. Academy of Management Annals, 5(1), 653-707.

Gómez-Mejía, L.R., Campbell, J.T., Martin, G., Hoskisson, R. E., Makri, M. and Sirmon, D.G., 2014. Socioemotional wealth as a mixed gamble: Revisiting family firm $R \& D$ investments with the behavioral agency model. Entrepreneurship Theory and Practice, 38(6), 1351-1374.

Gras, D. and Mendoza-Abarca, K.I., 2014. Risky business? The survival implications of exploiting commercial opportunities by nonprofits. Journal of Business Venturing, 29(3), 392-404.

Habbershon, T.G. and Williams, M.L., 1999. A resource-based framework for assessing the strategic advantages of family firms. Family Business Review, 12(1), 1-25.

Habbershon, T.G., Williams, M., Macmillan and Ian C., 2003. A unified systems perspective of family firm performance. Journal of Business Venturing, 18(4), p. 451-465.

Habbershon, T. G. and Pistrui, J., 2002. Enterprising families domain: Family-influenced ownership groups in pursuit of transgenerational wealth. Family Business Review, 15(3), 223-237.

Heirman, A. and Clarysse, B., 2007. Which tangible and intangible assets matter for innovation speed in start-ups? Journal of Product Innovation Management, 24(4), 303-315.

Hernández-Linares, R., and López-Fernández, M.C., 2018. Entrepreneurial orientation and the family firm: Mapping the field and tracing a path for future research. Family Business Review 31(3), 318-351.

Hernández-Perlines, F., and Cisneros, M.A.I., 2017. Analysis of the moderating effect of entrepreneurial orientation on the influence of social responsibility on the performance of Mexican family companies. Cogent Business \& Management, 4(1), 1408209.

Huergo, E. and Jaumandreu, J., 2004. How does probability of innovation change with firm age? Small Business Economics, 22(3-4), 193-207.

Huselid, M.A., 1995. The impact of human resource management practices on turnover, productivity, and corporate financial performance. Academy of Management Journal, 38(3), 635-672.

Hutchinson, R.W., 1995. The capital structure and investment decision of the small owner-managed firm: Some exploratory issues. Small Business Economics, 7(3), 231-239.

Kammerlander, N. and Ganter, M., 2015. An attention-based view of family firm adaptation to discontinuous technological change: Exploring the role of family CEOs' noneconomic goals. Journal of Product Innovation Management, 32(3), 361-383.

Kellerman, B., 2008. How followers are creating change and changing leaders. Boston, MA: Harvard School Press. 
Khan, U, Xuele, Z., Atlas, F. and Khan, F., 2019. The impact of dominant logic and competitive intensity on SMEs performance: A case from China. Journal of Innovation \& Knowledge, 4, 1-11.

Kupp, M., Schmitz, B. and Habel, J., 2019. When do family firms consider issuing external equity? Understanding the contingent role of families' need for control. Journal of Family Business Management, 9(3), 271-296.

Kotlar, J., De Massis, A., Fang, H. and Frattini, F., 2014. Strategic reference points in family firms. Small Business Economics, 43(3), 597-619.

Kotlar, J., Signori, A., De Massis, A., and Vismara, S., 2018. Financial wealth, socioemotional wealth, and IPO underpricing in family firms: A two-stage gamble model. Academy of Management Journal, 61(3), 1073-1099.

La Porta, R., Lopez-de-Silanes, F., and Shleifer, A., 1999. Corporate ownership around the world. Journal of Finance, 54(2), 471-517.

Lansberg, I. and Perrow, E., 1991. Understanding and working with leading family businesses in Latin America. Family Business Review, 4(2), 127-147.

Le Breton-Miller, I., Miller, D. and Lester, R.H., 2011. Stewardship or agen$c y$ ? A social embeddedness reconciliation of conduct and performance in public family businesses. Organization Science, 22(3), 704-721.

Lee, T. and Chu, W., 2017. The relationship between entrepreneurial orientation and firm performance: Influence of family governance. Journal of Family Business Strategy, 8(4), 213-223.

Litz, R.A., 2008. Two sides of a one-sided phenomenon: Conceptualizing the family business and business family as a Möbius strip. Family Business Review, 21, 217-236.

López-Fernández, M.C., Serrano Bedia, A. and Palama-Ruiz, M., 2016. What hampers innovation in Mexican familia firms? Academia Revista Latinoamericana de Administración, 29(3), 255-278.

Lumpkin, G.T. and Lichtenstein, B.B., 2005. The role of organizational learning in the opportunity-recognition process. Entrepreneurship Theory and Practice, 29(4), 451-472.

Malaver Rodríguez, F. and Vargas Pérez, M., 2004. Los procesos de innovación en la industria colombiana: Resultados de un estudio de casos. Academia Revista Latinoamericana de Administración, 33(2) 5-33.

Michiels, A. and Molly, V., 2017. Financing decisions in family businesses: a review and suggestions for developing the field. Family Business Review, 30(4), 369-399.

Miller, D., Wright, M., Breton-Miller, I.L. and Scholes, L., 2015. Resources and innovation in family businesses: The Janus-face of socioemotional preferences. California Management Review, 58(1), 20-40.

Monteferrante, P. and Piñango, R., 2011. Governance structures and entrepreneurial performance in family firms: an exploratory study of Latin American family firms. En M. Nordqvist et.al. (Eds.), Understanding Entrepreneurial Family Businesses in Uncertain Environments. Edward Elgar Publishing.

Morck, R. and Yeung, B., 2003. Agency problems in large family business groups. Entrepreneurship Theory and Practice, 27(4), 367-383.

Munari, F., Oriani, R. and Sobrero, M., 2010. The effects of owner identity and external governance systems on R\&D investments: A study of Western European firms. Research Policy, 39(8), 1093-1104.

Muñoz-Bullón, F. and Sánchez-Bueno, M., 2011. The impact of family involvement on the R\&D intensity of publicly traded firms. Family Business Review, 24(1), 62-70.

Murphy, L. and Lambrechts, F., 2015. Investigating the actual career decisions of the next generation: The impact of family business involvement. Journal of Family Business Strategy, 6(1), 33-44.

Naldi, L., Nordqvist, M., Sjöberg, K. and Wiklund, J., 2007. Entrepreneurial orientation, risk taking, and performance in family firms. Family Business Review, 20(1), 33-47.
Nicholson, E., 2011. Discovering Latin America and its family business. Tharawhat Magazine. www.thara-whatmagazine.com.

Nieto, M.J., Santamaria, L. and Fernández, Z., 2015. Understanding the innovation behavior of family firms. Journal of Small Business Management, 53(2), 382-399.

Nordqvist, M., Habbershon, T. G., and Melin, L., 2008. Transgenerational entrepreneurship: Exploring entrepreneurial orientation in family firms. Entrepreneurship, sustainable growth and performance: Frontiers in European entrepreneurship research, 93.

Nordqvist, M., Marzano, G., Brenes, E. R., Jiménez, G. and Fonseca-Parades, M., 2011. Understanding entrepreneurial family businesses in uncertain environments: The case of Latin America. In Understanding Entrepreneurial Family Businesses in Uncertain Environments. Edward Elgar Publishing.

Olavarrieta, S. and Villena, M.G., 2014. Innovation and business research in Latin America: An overview. Journal of Business Research, 67(4), 489-497.

Orlitzky, M, Schmidt, F.L Rynes and Reynes, S., 2003. Corporate social and financial performance: A meta-analysis. Organization Studies, 24 (3), 403-441.

Ostrom, E., 2005. Undestanding instituional diversity. Princenton University Press.

Pavitt, K., 2005. Innovation process, En Fagerberg, et al (eds.), The Oxford handbook of innovation, 86-114, Oxford: Oxford University Press.

Pérez, P. F. and Lluch, A. (Eds.), 2016. Evolution of family business: Continuity and change in Latin America and Spain. Edward Elgar Publishing.

Pindado, J., Requejo, I. and de la Torre, C., 2011. Family control and investment-cash flow sensitivity: Empirical evidence from the Euro zone. Journal of Corporate Finance, 17(5), 1389-1409.

Pindado, J. and Requejo, I., 2014. Panel data: a methodology for model specification and testing. Wiky Enciclopedia of Manager, Cooper, C.L. (ed.). Ed John Wiley \& Sons, Ltd.

Poza, E.J., 1995. Global competition and the family-owned business in Latin America. Family Business Review, 8(4), 301-311.

Querbach, S., Bird, M., Kraft, P.S. and Kammerlander, 2020. When the former CEO stays on board: The role of the predecessor's board retention for product innovation in family firms. Journal of Product Innovation Management, 37(2), 184-207.

Ridder, A-K., 2012. External dynamics capabilities: Creating competitive advantages in Innovation via external resources renewal, WP2012. School of Business Economics, Maastrich University.

Roberts, P.W. and Dowling, G.R., 2002. Corporate reputation and sustained superior financial performance. Strategic Management Journal, 23(12), 1077-1093.

Robles, T.F., Carroll, J.E., Bai, S., Reynolds, B.M., Esquivel, S. and Repetti, R. L., 2016. Emotions and family interactions in childhood: Associations with leukocyte telomere length. Psychoneuroendocrinology, $63,343-350$

Rua, O.L., 2018. From intangible resources to export performance. Review of International Business and Strategy, 28(1), 224-242.

Sapra, H., Subramanian, A. and Subramanian, K., 2014. Corporate governance and Innovation: Theory and evidence, Journal of Financial and Quantitative Analysis, 49(4), 957-1003.

Sciascia, S., Mazzola, P. and Chirico, F., 2013. Generational involvement in the top management team of family firms: Exploring nonlinear effects on entrepreneurial orientation. Entrepreneurship Theory and Practice, 37(1), 69-85.

Schneider, B.R., 2009. Hierarchical market economies and varieties of capitalism in Latin America. Journal of Latin American Studies, 41(3), 553-575.

Schoorman, F.D., Mayer, R.C. and Tagi, J.H., 2007. An Integrative model of organizational trust: Past, present, and future. Academy of Management Review, 32(2), 344- 354. 
Schumpeter, J.A., 1934. The theory of economic development, Cambridge, MA: Harvard University Press.

Schumpeter, J.A., 1942. Capitalism, socialism and democracy. New York: Harper and Row.

Sharma, P. and Chua, J.H., 2013. Asian family enterprises and family business research. Asia Pacific Journal of Management, 30, 641-656.

Shrivastava, P. and Grant, J.H., 1985. Empirically derived models of strategic decision-making processes. Strategic Management Journal, 6(2), 97-113.

Steir, L., 2003. Variants of agency contracts in family financed ventures as a continuum of familial altruistic and market rationalities. Journal of Business Venturing, 18(5), 597-618.

Stoney, C. and Winstanley, D., 2001. Stakeholding: confusion or utopia? Mapping the conceptual terrain. Journal of Management Studies, 38(5), 602-626.

Surroca, J., Tribó, J.A. and Waddock, S., 2010. Corporate responsibility and financial performance: The role of intangible resources. Strategic Management Journal, 31(5), 463-490.

Thornton, P.H. and Ocasio, W., 2008. Institutional logics. En R. Greenwood, C. Oliver, y R. Suddaby (Eds.), The Sage handbook of organizational institutionalism. Thousand Oaks, CA: Sage, 99-128.

Talke, K., Salomo, S. and Rost, K., 2010. How top management team diversity affects innovativeness and performance via the strategic choice to focus on innovation fields. Research Policy, 39(7), 907-918.

Teece, D.J., 2007. Explicating dynamic capabilities: the nature and microfoundations of (sustainable) enterprise performance. Strategic Management Journal, 28(13), 1319-1350.

Trott, P., 2008. Innovation management and new Product development. Harlow, UK: Financial Times/Prentice Hall.
Ughetto, E., 2010. Assessing the contribution to innovation of private equity investors: a study on European buyout. Research Policy, 39(1), 126-140.

Van der Wijst D., 1989. Small Business Characteristics. In: Financial Structure in Small Business. Lecture Notes in Economics and Mathematical Systems, vol 320. Springer, Berlin, Heidelberg. 11-26.

Van Doorn, S., Jansen, J.J., Van den Bosch, F.A. and Volberda, H.W., 2013. Entrepreneurial orientation and firm performance: Drawing attention to the senior team. Journal of Product Innovation Management, 30(5), 821-836.

White, H., 1980. A heteroscedastic-consistent covariance matrix estimator and a direct test for heteroscedasticity. Econometrica, 48, 817-838.

Wu, L.Y., 2010. Applicability of the resource-based and dynamic-capability views under environmental volatility. Journal of Business Research, 63(1), 27-31.

Zahra, S.A., 2005. Entrepreneurial risk taking in family firm. Family Business Review, 18(1), 23-40,

Zahra, S.A., Hayton, J.C., Neubaum, D.O., Dibrell, C. and Craig. J., 2008. Culture of family commitment and strategic flexibility: The moderating effect of stewardship. Entrepreneurship Theory and Practice, 32(6), 1035-1054.

Zattoni, A., Gnan, L. and Huse, M., 2015. Does family involvement influence firm performance? Exploring the mediating effects of board processes and tasks. Journal of Management, 41(4), 1214-1243.

Zellweger, T., 2007. Time horizon, costs of equity capital, and generic investment strategies of firms. Family business review, 20(1), 1-15.

Zellweger, M., Eddleston, K.A., and Kellermans, F.W., 2010. Exploring the concept of familiness: Introducing family firm identity. Journal of family Business Strategy, 1(1), 54-63. 